\title{
Delivery of zooplankton to the surf zone during strong internal tidal forcing and onshore winds in Baja California
}

\author{
R. G. Fernández-Aldecoa ${ }^{1}$, L. B. Ladah ${ }^{1, *}$, S. G. Morgan ${ }^{2}$, C. D. Dibble ${ }^{2}$, \\ E. Solana-Arellano ${ }^{3}$, A. Filonov ${ }^{4}$ \\ ${ }^{1}$ Dept. of Biological Oceanography, CICESE, Carretera Ensenada-Tijuana \#3918, Zona Playitas, CP 22860 Ensenada, \\ Baja California, México \\ ${ }^{2}$ Bodega Marine Laboratory, University of California Davis, 2099 Westshore Drive, Bodega Bay, California 94923, USA \\ ${ }^{3}$ Dept. of Marine Ecology, CICESE, Carretera Ensenada-Tijuana \#3918, Zona Playitas, CP 22860 Ensenada, Baja California, \\ México \\ ${ }^{4}$ Physics Department, University of Guadalajara, Blvd. Marcelino García Barragán \#1421, Esq. Calzada Olímpica, \\ CP 44430 Guadalajara, Jalisco, México
}

\begin{abstract}
Various physical mechanisms are implicated in the transport of zooplankton to the outer edge of the surf zone, which is the final barrier before reaching the adult habitat of many meroplanktonic organisms. To explore these physical mechanisms, we measured the abundance of zooplankton in the surf zone hourly for 3 consecutive days during strong internal tidal forcing while concurrently measuring winds, currents, and seawater temperature. Strong temperature changes in the water column that were associated with internal tidal bores, as well as onshore coastal winds, coincided with peaks in abundance of barnacle cyprids, gastropods, and bryozoan larvae in the surf zone. This study supports the hypothesis that both internal tidal bores and onshore winds can accumulate zooplankton nearshore, and that these transport mechanisms may act in concert.
\end{abstract}

KEY WORDS: Zooplankton · Larval supply $\cdot$ Internal tidal bore $\cdot$ Onshore winds $\cdot$ Surf zone $\cdot$ Rocky shore

\section{INTRODUCTION}

Delivery of planktonic larvae to the intertidal zone is necessary for the persistence of coastal marine populations. Larvae are transported across the shelf by one or more mechanisms, including wind-driven surface currents, upwelling and relaxation circulation, and breaking internal tidal waves, often termed bores (Ladah et al. 2005, Jacinto \& Cruz 2008, Shanks et al. 2014, Morgan et al. 2018). Subsequent transport into and across the surf zone occurs through similar mechanisms (Shanks 1995, Pfaff et al. 2015, Morgan et al. 2018), including onshore winds, Stokes drift from breaking surface waves, non-linear or breaking internal waves or bores, and benthic streaming (for organisms near the bottom) due to the dissipation of

${ }^{*}$ Corresponding author: lladah@cicese.mx energy in the wave boundary layer near the bottom (Fujimura et al. 2014, Shanks et al. 2014, Navarrete et al. 2015).

Plankton can be transported onshore by winds, which can result from various mechanisms. The sea breeze, which occurs due to a temperature gradient that is generated between the land and the ocean, can result in onshore surface currents of up to $10 \mathrm{~cm}$ $\mathrm{s}^{-1}$ over an area of influence of about $3 \mathrm{~km}$ from shore (Tapia et al. 2004, Woodson et al. 2007), and can transport surface zooplankton shoreward (Shanks 1995). Wind-forced upwelling-downwelling circulation occurs when equatorward winds, generally associated with large-scale geostrophic pressure systems, displace coastal surface waters offshore due to Ekman transport, which are replaced with colder,

() The authors 2019. Open Access under Creative Commons by Attribution Licence. Use, distribution and reproduction are unrestricted. Authors and original publication must be credited. 
denser, upwelled waters that can transport zooplankton from deeper layers shoreward. When these winds relax or change direction, the colder and denser waters sink, and the warmer surface waters that were initially pushed offshore return to shore, transporting surface zooplankton shoreward (Wing et al. 1995, Shanks et al. 2000, Almeida \& Queiroga 2003).

Planktonic larvae can also be transported onshore by internal tidal bores, which generally occur in 2 phases (Pineda 1994, 1999). As the internal tide, which is an internal wave of tidal frequency, enters shallow waters, it becomes unstable and breaks, causing waters from below the thermocline to shoal and move shoreward, known as the cold phase or bore (Pineda 1991). Afterwards, as the cold, dense water sinks and is advected offshore, warmer surface waters move back onshore, called the warm phase or bore. These 2 alternating phases occur once each tidal cycle and are characteristic of a mode-1 internal wave, with currents flowing in opposite directions above and below the thermocline (Shanks 1983, Pineda et al. 2007). Therefore, for a semidiurnal internal tide, 2 cold and 2 warm bores are expected each day. Warm bores have been shown to transport organisms that are near the surface in the direction of the propagating wave (Pineda 1991, Leichter et al. 1998), while cold bores can transport organisms from deeper strata in the direction of the propagating wave (Pineda 1994).

After marine invertebrate larvae have been transported nearshore, the surf zone represents the final barrier that they must cross to reach their adult habitat in the intertidal zone (Rilov et al. 2008, Morgan et al. 2017, 2018). Surf zone hydrodynamics affect the supply of larvae to the intertidal zone and can vary greatly depending on beach morphology, breaking surface waves, and currents (Pfaff et al. 2015, Morgan et al. 2018). Dissipative beaches are characterized by high wave energy, wide surf zones, and finegrain sand (Thornton \& Guza 1983). Plankton can cross dissipative beaches through transport forced by onshore winds at the surface, Stokes drift from breaking surface waves (Tilburg 2003, Fewings et al. 2008, Lentz et al. 2008), or benthic streaming. Reflective beaches, on the other hand, are characterized by lower wave energy, narrow energetic surf zones and narrow rocky beaches (Elgar et al. 1994). Many of the same cross-shore processes occur on reflective beaches (albeit with a much narrower surf zone to cross), such as Stokes drift, onshore wind-driven currents for near-surface organisms, internal bores, and benthic streaming for bottom organisms (Fujimura et al. 2014, Shanks et al. 2014, Navarrete et al. 2015, Morgan et al. 2018). However, the cross-shore pro- cesses at reflective beaches have been much less studied, and are less efficient compared to those on dissipative beaches due to the lack of rip currents, the reduced undertow, and the narrow surf zone.

Semidiurnal internal waves have been well characterized in the northern part of the Bay of Todos Santos, Baja California, Mexico (Ladah et al. 2005, 2012, Filonov et al. 2014). In this area, internal tidal bores have been shown to modulate changes in the vertical distribution, abundance, and settlement of meroplankton. Liévana MacTavish et al. (2016) showed significant changes in the vertical distribution and abundance of barnacle and crabs in the water column across internal tidal fronts, and internal tidal bores have been associated with settlement of the barnacle Chthamalus spp. in the intertidal zone (Ladah et al. 2005, Valencia-Gasti \& Ladah 2016). Internal tidal bores occur on every continental shelf (Shanks 1995, Leichter et al. 2005), and because they may be critical for cross-shelf and surf zone transport of many marine larvae, exploring their ability to deliver plankton to nearshore waters is necessary for understanding the dynamics of coastal populations (Franks 1997, Helfrich \& Pineda 2003), particularly on less-studied reflective beaches.

We aimed to evaluate high-frequency changes (hourly) in the abundance of target meroplankters (gastropods, mussels, oysters, barnacles, crabs, bryozoans, and cyprids) and holoplankton (foraminifera and ostracods) in the surf zone during a period of strong internal tidal forcing in summer, when many larvae settle and recruit in this area. Concurrent measurements of temperature, currents, and winds helped to identify the mechanisms occurring while zooplankton abundance was measured. We hypothesized that significant increases in the abundance of the zooplankters would occur during rapid temperature changes, related to internal tidal bores reaching the surf zone.

\section{MATERIALS AND METHODS}

\subsection{Study area}

The study was conducted in Playa San Miguel, a rocky wave-exposed beach located in the northern part of the Bay of Todos Santos, Baja California, Mexico $\left(31^{\circ} 55^{\prime} \mathrm{N}, 116^{\circ} 38^{\prime} \mathrm{W}\right)$, near Ensenada. The coastline orientation is $47^{\circ}$ from geographic true north (facing the southeast) at this shore, and it is classified as a reflective beach due to its steep shore, narrow and energetic surf zone, and narrow beach with large boul- 
ders. Summertime conditions are characterized by a highly stratified water column, with strong semidiurnal internal wave activity (Ladah et al. 2005).

\subsection{Data collection}

Zooplankton samples were collected every hour in triplicate for 3 continuous days from 31 August to 3 September 2015 from the low intertidal/shallow subtidal, using pumps connected to wide-mouthed hoses (5.08 $\mathrm{cm}$ diameter). One end of the hose was weighted and anchored to sample at $20 \mathrm{~cm}$ from bottom. The other end of the hose fed into a nytex $(150 \mu \mathrm{m})$ mesh bag to collect filtrate. Pump rates were adjusted and standardized to collect $100 \mathrm{l}$ of water. The contents were filtered and fixed in $92 \%$ ethanol immediately after collection. The high-frequency sampling was essential for detecting changes that occur at hourly scales in response to breaking internal tidal waves at the coast. Identification to the lowest taxonomic level was performed using a stereomicroscope (32× objective). All meroplankton taxa and the most abundant holoplankton taxa were enumerated.

A set of instruments and a weather station recorded physical variables near the study area. Temperature of the water column was measured using a ver- tical array of thermistors $\left(\mathrm{HOBO}^{\circledR}\right.$ Tidbit v2; Onset) deployed every $1 \mathrm{~m}$ at 2 mooring stations located 450 and $850 \mathrm{~m}$ offshore of the intertidal site, in 5 and $15 \mathrm{~m}$ depth, respectively (Fig. 1). Instruments recorded temperature every $1 \mathrm{~min}$. This type of array has been used to identify internal waves with periods greater than 10 min at this site (see Ladah et al. 2012, Filonov et al. 2014). Winds were measured every 5 min from the CICESE Observatory at El Sauzal (http://observatorio.cicese.mx/cicese/Current_cicese.htm), located $2 \mathrm{~km}$ from the study area. Tidal heights, specific for this bay, were provided by the MAR program v.1.0 2011 (http://predmar.cicese.mx/). A $600 \mathrm{kHz}$ acoustic Doppler current profiler (ADCP; RDI workhorse, http:// www.teledynemarine.com/workhorse-sentinel-adcp? BrandID =16) was deployed at $15 \mathrm{~m}$ depth and set to record every $1 \mathrm{~min}$ in $1 \mathrm{~m}$ bins.

\subsection{Data processing}

Rapid temperature changes characteristic of internal waves were explored using the absolute value of the difference of temperature at the $5 \mathrm{~m}$ depth mooring every $1 \mathrm{~h}$ to correspond with hourly plankton samples:

$$
\Delta^{\circ} \mathrm{C}=1{ }^{\circ} \mathrm{C}_{t+1 \mathrm{~h}}-{ }^{\circ} \mathrm{C}_{t} \mid
$$

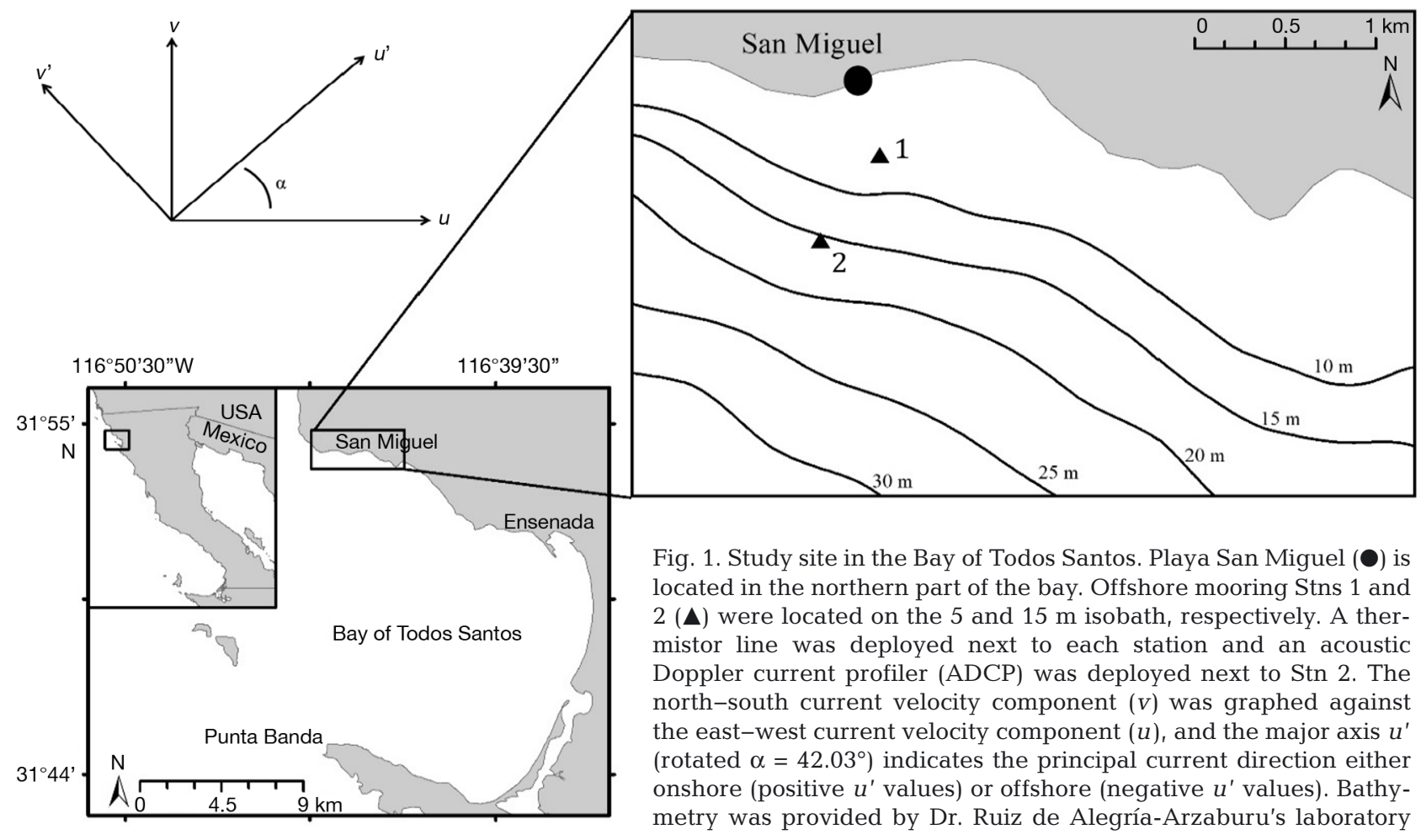


where ${ }^{\circ} \mathrm{C}_{t}$ is the temperature at time 1 and ${ }^{\circ} \mathrm{C}_{t+1 \mathrm{~h}}$ is the temperature $1 \mathrm{~h}$ later. Temperature data were taken from the $3 \mathrm{~m}$ depth thermistor, creating a new time series used in further analyses explained below.

Wind speeds and direction were decomposed into their Cartesian components $u$ (east-west) and $V$ (north-south). Similarly, current velocity components were decomposed. To calculate the horizontal component with the greatest variability, we used the following equation:

$$
u^{\prime}=u \cos (\alpha)+v \sin (\alpha)
$$

The angle between the reference system of $u$ and the reference system of $u^{\prime}$ for current velocity was $\alpha$ (Fig. 1). Positive $u^{\prime}$ current velocities indicate current propagation towards the northern part of the bay (onshore), while negative $u^{\prime}$ velocities indicate current propagation away from the study site (offshore). For wind speed, the angle between the reference system of $u$ and $u^{\prime}$ was $\alpha=-21.6^{\circ}$. Shoreline orientation of the study site faced southeast. Thus, a westnorthwesterly sea breeze corresponds to cross-shore winds, with positive velocities indicating onshore winds, while negative velocities indicate offshore winds. The $V^{\prime}$ component of the wind had a northsouth principal direction at the study site.

\subsection{Data analysis}

Because high-resolution measurements were taken over time, autocorrelation in the zooplankton data set was expected, potentially resulting in nonindependence of data. To remove the autocorrelation, we fit an autoregressive integrated moving average (ARIMA) model to the zooplankton data. The residuals from the ARIMA model were then used in the ANOVA and generalized linear models (GLMs), to avoid the problem of non-independence. A 1-way ANOVA with $\alpha=0.05$ was performed to determine differences in the abundance of larvae with a posteriori comparisons using Fisher's least significant difference (LSD) test (StatSoft). GLMs (with identity link function) were performed, where rapid temperature change (see Eq. 1 above), wind speed $u^{\prime}$ and $v^{\prime}$ (see Eq. 2 above), tidal height and their interactions were used as predictors for zooplankton abundance for every taxon. Akaike's information criteria (AIC), the proportion of the explained deviance $\left(D^{2}\right)$, and the independence of the residuals from the model (Durbin-Watson test), were used as criteria to identify which physical mechanism best explained the variability of zooplankton abundance in the surf zone. Spectral analyses were used to determine patterns in the vertical and temporal variability in the temperature time series at both moorings, and coherence analyses were used to explore the relationship of temperature variability with the tide and the sea breeze. Periodograms were smoothed to just 3 frequencies due to the short sampling period $(7 \mathrm{~d} ; 27$ August to 2 September 2015).

\section{RESULTS}

\subsection{Internal tidal bores nearshore}

Water-column temperature at the $15 \mathrm{~m}$ mooring station showed diurnal fluctuations in temperature near the surface, with a stronger semidiurnal signal $(12.4 \mathrm{~h})$ below the thermocline and near the bottom (Fig. 2a). Temperature differences between the surface and bottom were over $5^{\circ} \mathrm{C}$ during periods of high stratification (Fig. 3d). Cold and warm water fronts alternated approximately every $6 \mathrm{~h}$ and coincided with fluctuations of the thermocline and movement of water in opposite directions above and below

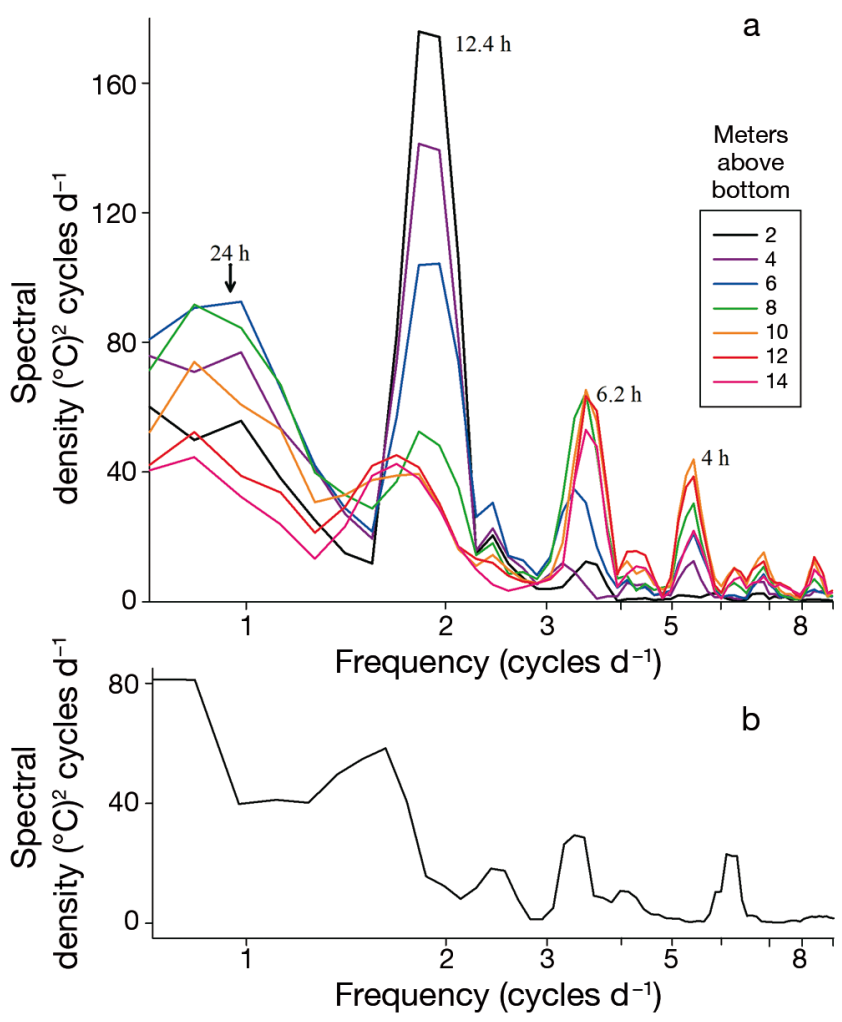

Fig. 2. Spectra (periodogram, cycles $\mathrm{d}^{-1}$ ) of temperature at the (a) $15 \mathrm{~m}$ and (b) $5 \mathrm{~m}$ moorings. All depths were averaged for the $5 \mathrm{~m}$ mooring 

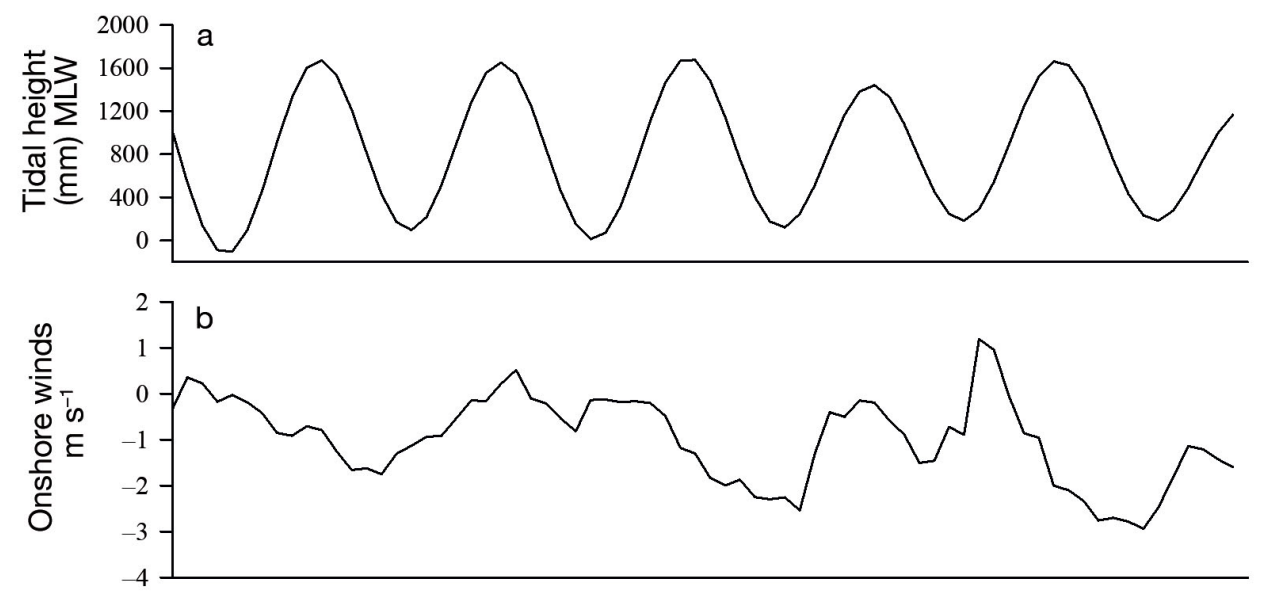

Fig. 3. Time series of (a) tidal height at San Miguel beach at mean low water (MLW) reference, (b) cross-shore wind velocity (positive values are onshore winds and negative values are offshore winds) and (c) cross-shore current velocity $\left(u^{\prime}\right)$ at 3 and $11 \mathrm{~m}$ above bottom (mab) - positive values are onshore flow and negative values are offshore flow. Temperature of the water column at the (d) 15 $\mathrm{m}$ and (e) $5 \mathrm{~m}$ mooring stations; warm and cold fronts advecting to the intertidal are numbered and shown by dashed lines in (d)
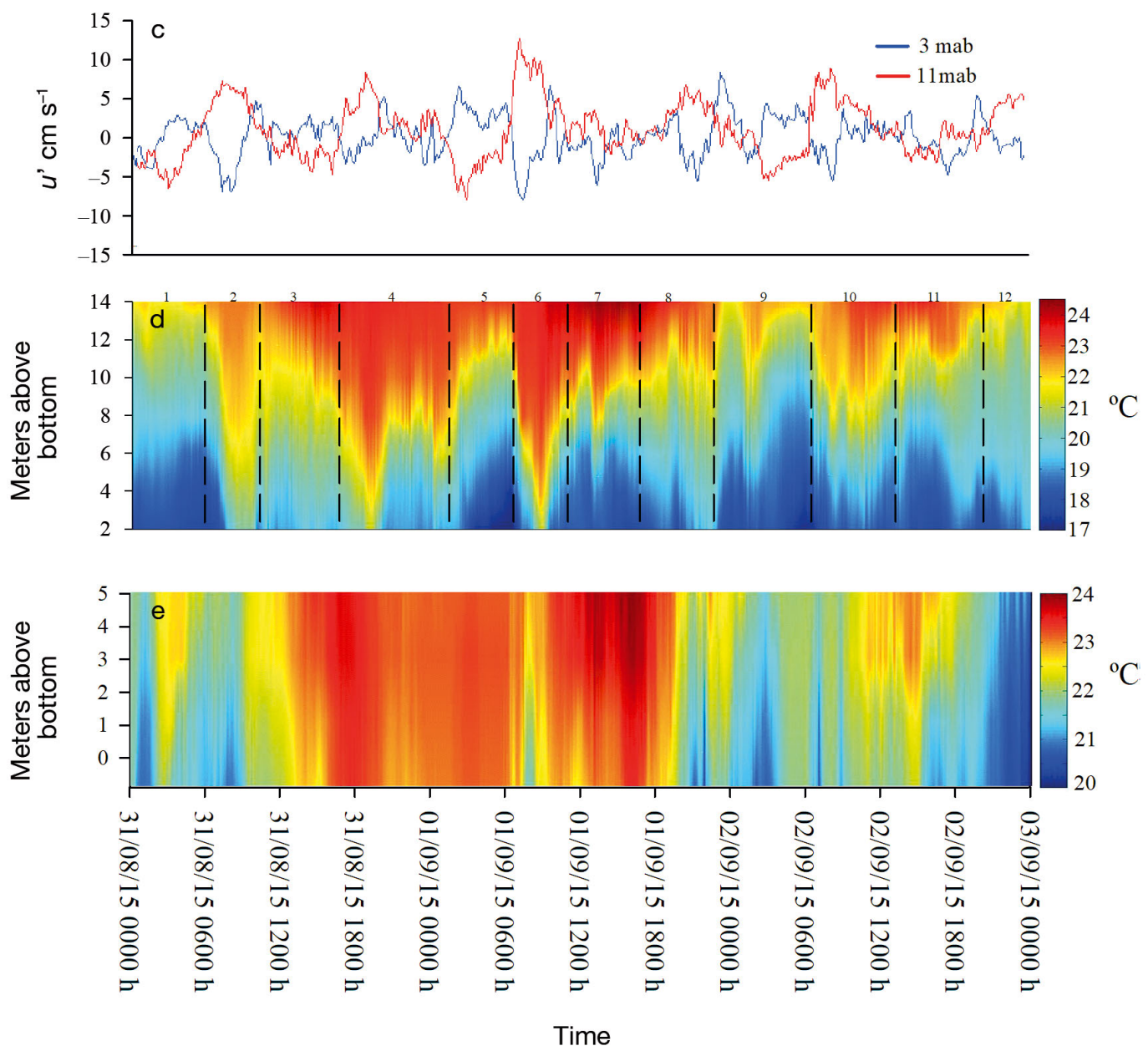

the thermocline. For example, a cold front was detected on 1 September starting at around $02: 00 \mathrm{~h}$ and ending at 07:00 h, with currents flowing in the southwestern direction (offshore flow) near the surface, while bottom currents showed a northeastern direction (onshore flow). Following the cold front, the temperature of the water column abruptly increased, and a warm front began around 08:00 $\mathrm{h}$ and ended at
12:00 $\mathrm{h}$, with currents switching direction above and below the thermocline.

Nearer to shore, at the $5 \mathrm{~m}$ mooring station, strong internal tidal bores were apparent in the temperature time series, resulting in periods of little to no stratification that lasted at times longer than the expected $6 \mathrm{~h}$ periods (Fig. 3e). For example, on 31 August around 09:00 $\mathrm{h}$, the water column temperature was 
below $21^{\circ} \mathrm{C}$. Following this event, the entire water column warmed, and $4 \mathrm{~h}$ later reached above $23^{\circ} \mathrm{C}$. The spectral analysis of the averaged water column temperature at the $5 \mathrm{~m}$ mooring generally showed a weaker peak in the semidiurnal band than the temperature at most depths of the $15 \mathrm{~m}$ mooring (Fig. 2b).

During the $3 \mathrm{~d}$ of sampling, 12 cold or warm fronts reached the nearshore site (Fig. 3d). The bores were highly non-linear, most of them breaking before reaching the subtidal, resulting in strong watercolumn temperature changes for at least a few hours in most cases. However, on 31 August, the strongest warm front of the study period arrived and temperature was maintained around $24^{\circ} \mathrm{C}$ for a full $16 \mathrm{~h}$ (Fig. 3e).

\subsection{Sea breeze}

Cross-shore winds were dominant during our study. Higher wind speeds occurred in the afternoons (Fig. 3b). The offshore component reached a maximum of nearly $3 \mathrm{~m} \mathrm{~s}^{-1}$ while onshore winds only reached $1 \mathrm{~m} \mathrm{~s}^{-1}$. Water-column temperature at the $15 \mathrm{~m}$ mooring and the sea breeze were coherent in the diurnal band and in phase near the surface layer (Fig. 4).

\subsection{Delivery of zooplankton to intertidal}

The vast majority (85\%) of the enumerated zooplankters were late-stage larvae (Table 1). Gastropods (late larvae) and foraminifera were the most abundant of meroplankton and holoplankton taxa, respectively. Zooplankton arrived to shore in pulses (Fig. 5), with nearly $60 \%$ of organisms arriving in a span of $6 \mathrm{~h}$ (12:00 to 18:00 h on 31 August).

The GLM explained the abundance patterns of gastropods, foraminifera, cyphonautes (bryozoan larvae), and barnacle cyprids (Table 2). For both gastropods and foraminifera, the models that incorporated all of the factors (changes in temperature, cross-shore winds, north-south winds, and tidal height) and their interactions best explained the abundance patterns. However, for cyphonautes and barnacle cyprids, the models that incorporated temperature change, tidal height, and only the northsouth winds showed the best fit.

GLM analysis showed that rapid temperature changes, most likely related to tidal bores advecting to the nearshore, explained nearly $25 \%$ of barnacle

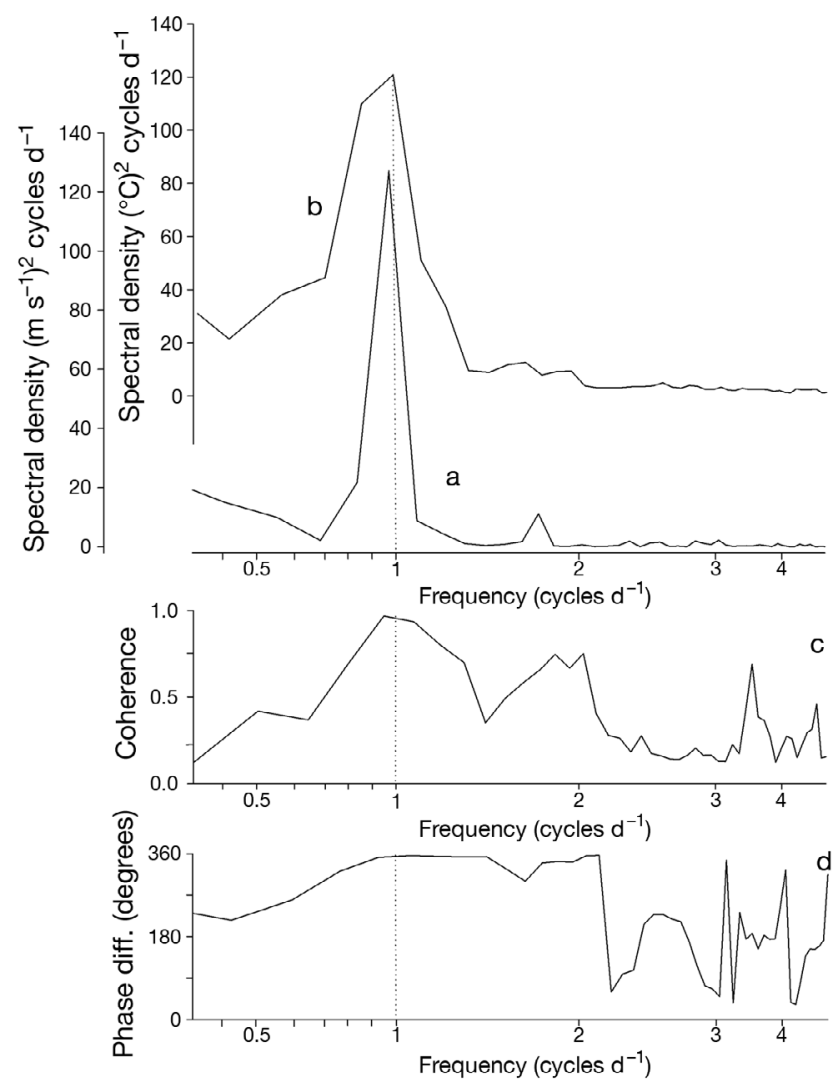

Fig. 4. Spectral density (cycles $\mathrm{d}^{-1}$ ) between the sea breeze $\left(u^{\prime}\right)$ and temperature of the surface layer is shown. Vertical dashed lines represent the diurnal band of the (a) wind component $u^{\prime}$ and (b) temperature at $14 \mathrm{~m}$ above the bottom (near the surface); (c) coherence and (d) phase difference

Table 1. Mean (+SE) concentration (no. of zooplankters per $100 \mathrm{l}$ ) and percentage of zooplankton collected from 31 August to 3 September 2015 at San Miguel Beach

\begin{tabular}{|lrrr|}
\hline Taxon & Mean & SE & $\%$ \\
\hline Gastropod late larvae & 131.96 & 16.34 & 76.25 \\
Foraminifera & 14.63 & 3.22 & 8.46 \\
Ostracods & 10.54 & 1.70 & 6.09 \\
Mytilus spp. late larvae & 7.56 & 1.71 & 4.37 \\
Crassostrea spp. late larvae & 3.24 & 0.86 & 1.87 \\
Cyphonautes & 2.98 & 0.54 & 1.72 \\
Barnacle cyprids & 1.66 & 0.89 & 0.96 \\
Larvaceans & 0.30 & 0.17 & 0.17 \\
Crab zoea & 0.11 & 0.09 & 0.06 \\
Barnacle nauplii & 0.07 & 0.05 & 0.04 \\
\hline
\end{tabular}

cyprid variability (Table 3 ). Also, the interaction between rapid temperature changes and cross-shore winds played an important role, explaining more than 30 and $25 \%$ of gastropod larvae and foraminifera variability, respectively. For example, during a 

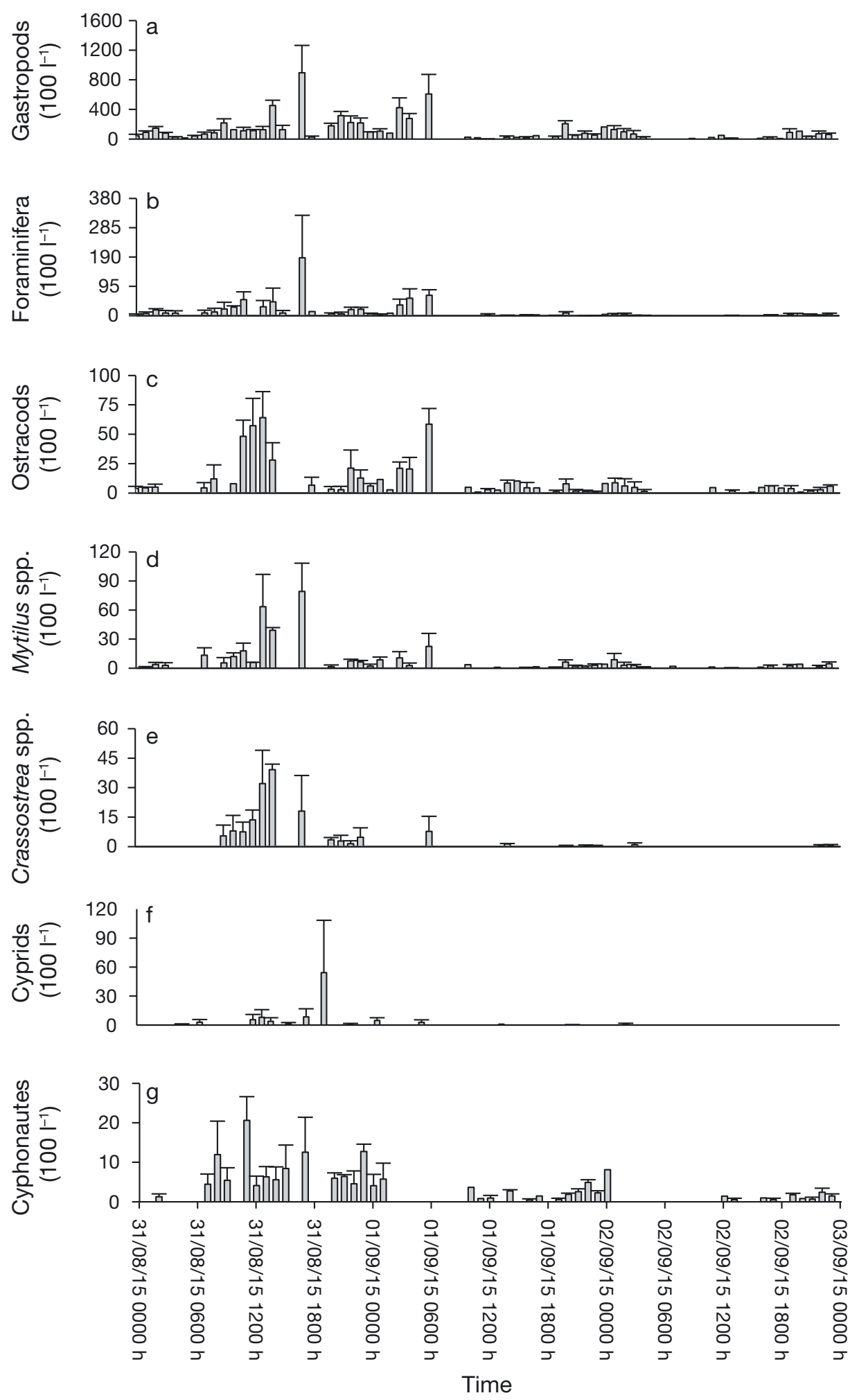

Fig. 5. Time series of the most abundant zooplankton taxa: (a) gastropods (late-stage larvae), (b) Foraminifera, (c) ostracods, (d) Mytilus spp. (late-stage larvae), (e) Crassostrea spp. (late-stage larvae); (f) barnacle cyprids, and (g) cyphonautes. Error bars are $\pm \mathrm{SE}$ 
Table 2. Models representing hypotheses of onshore larval transport at San Miguel beach. Model selection was based on lowest Akaike's information criteria (AIC) values and independence of residuals (Durbin-Watson [D-W] statistic). Factors used in the candidate models included changes in temperature $\left(\Delta^{\circ} \mathrm{C}\right)$, cross-shore winds $\left(W_{\mathrm{cs}}\right)$, north-south winds $\left(W_{\mathrm{ns}}\right)$, and tidal height $(T)$. $K$ : number of parameters included in the model. AIC and results from the D-W test are shown

\begin{tabular}{|c|c|c|c|c|c|c|c|}
\hline Taxon & Candidate model & $K$ & AIC & Lag & $\begin{array}{c}\text { Auto- } \\
\text { correlation }\end{array}$ & $\begin{array}{c}\mathrm{D}-\mathrm{W} \\
\text { statistic }\end{array}$ & $\begin{array}{c}\mathrm{p}- \\
\text { value }\end{array}$ \\
\hline Gastropods & $\begin{array}{l}\Delta^{\circ} \mathrm{C}+W_{\mathrm{ns}}+W_{\mathrm{cs}}+T+\Delta^{\circ} \mathrm{C} \times\left(W_{\mathrm{ns}}+W_{\mathrm{cs}}+T\right)+ \\
W_{\mathrm{ns}} \times\left(W_{\mathrm{cs}}+T\right)+\left(W_{\mathrm{cs}} \times T\right)+\left(\Delta^{\circ} \mathrm{C} \times W_{\mathrm{ns}} \times T\right)+ \\
\left(\Delta^{\circ} \mathrm{C} \times W_{\mathrm{cs}} \times T\right)+\left(W_{\mathrm{ns}} \times W_{\mathrm{cs}} \times T\right)\end{array}$ & 15 & 786.94 & 1 & 0.04 & 1.91 & 0.37 \\
\hline Foraminifera & $\begin{array}{l}\Delta^{\circ} \mathrm{C}+W_{\mathrm{ns}}+W_{\mathrm{cs}}+T+\Delta^{\circ} \mathrm{C} \times\left(W_{\mathrm{ns}}+W_{\mathrm{cs}}+T\right)+ \\
W_{\mathrm{ns}} \times\left(W_{\mathrm{cs}}+T\right)+\left(W_{\mathrm{cs}} \times T\right)+\left(\Delta^{\circ} \mathrm{C} \times W_{\mathrm{ns}} \times T\right)+ \\
\left(\Delta^{\circ} \mathrm{C} \times W_{\mathrm{cs}} \times T\right)+\left(W_{\mathrm{ns}} \times W_{\mathrm{cs}} \times T\right)\end{array}$ & 15 & 573.12 & 1 & -0.26 & 2.53 & 0.09 \\
\hline Cyphonautes & $\Delta^{\circ} \mathrm{C}+T+\left(\Delta^{\circ} \mathrm{C} \times T\right)$ & 3 & 332.1 & 1 & -0.02 & 2.05 & 0.98 \\
\hline Barnacle cyprids & $\begin{array}{l}\Delta^{\circ} \mathrm{C}+W_{\mathrm{ns}}+T+\Delta^{\circ} \mathrm{C} \times\left(W_{\mathrm{ns}}+T\right)+\left(W_{\mathrm{ns}} \times T\right)+ \\
\left(\Delta^{\circ} \mathrm{C} \times W_{\mathrm{ns}} \times T\right)\end{array}$ & 7 & 410.12 & 1 & 0.07 & 1.85 & 0.33 \\
\hline
\end{tabular}

warm bore arrival between 13:00 and 18:00 $\mathrm{h}$ on 31 August, over $25 \%$ of all zooplanktonic organisms collected during the entire study were found. The tide also explained $10 \%$ of the variability of cyphonautes.

\section{DISCUSSION}

Rapid changes in temperature associated with internal tidal bores reaching the coast significantly explained the abundance patterns of late-stage larvae at an hourly scale on this reflective shore. For some organisms, there was also a significant interaction between internal tidal bores and onshore winds. Although in other studies these factors have been found to independently have a significant relationship with larval concentrations or larval settlement (Pineda 1994, Tapia et al. 2004, Ladah et al. 2005, Shanks et al. 2014), our results support the proposal that, for some taxa, both factors might act in concert to deliver larvae to the surf zone.

At the $15 \mathrm{~m}$ mooring station, semidiurnal internal waves were detected propagating across the shore. An alternating pattern of colder and warmer waters occurred approximately every $6 \mathrm{~h}$, with circulation above and below the thermocline flowing in opposite directions, as expected for a semidiurnal mode- 1 internal tide. Mode- 1 internal waves have been previously observed at this site in the nearshore water column during stratified conditions and strong atmospheric tides (Filonov et al. 2014). This circulation pattern follows the model proposed by Pineda (2000), showing how different phases of an internal bore can theoretically transport larvae to the coast as a function of depth.
In contrast, at the $5 \mathrm{~m}$ mooring station located $400 \mathrm{~m}$ from shore, just offshore of the surf zone, the shallow water column was completely flooded by either colder or warmer waters at a time. Water column temperatures showed little stratification, internal waves did not show the expected mode-1 signature, and there was no clear pattern of alternating warm and cold bores. The semidiurnal frequency typical of internal waves that was found at the $15 \mathrm{~m}$ mooring and that has been found previously at this site (Ladah et al. 2005, 2012, Filonov et al. 2014) was not present in the $5 \mathrm{~m}$ mooring data, suggesting that as the internal waves propagated across the shore into shallower water, they broke up and overturned the water column. Warm bores were often strong enough to persist over more than the semidiurnal cycle, as subsequent bores did not replace the warm water that had been mixed onto the shelf. Circulation and retention times of bores in such shallow water have not been well studied and could be important in the delivery and retention of larvae (Mateos et al. 2009, Filonov et al. 2014).

For bryozoans (cyphonautes), tidal height was the factor that best explained their abundance patterns. Saunders \& Metaxas (2010) suggested that onshore transport of cyphonautes occurs during wind-driven downwelling events; however, in our study we did not have any such events. Differences found in the delivery mechanism between studies may be related to regional variability in the vertical distribution of larvae. For example, Saunders \& Metaxas (2010) found higher abundances of cyphonautes closer to the surface in Nova Scotia, whereas in California, near our study site, other authors (Bernstein \& Jung 1979, Yoshioka 1982, Pineda 1999) found that they occurred below the thermocline in strongly stratified 
Table 3. Results from general linear model analysis of the effect of physical factors on zooplankton concentrations (gastropods, foraminifera, cyphonautes, and barnacle cyprids). Significant $(\mathrm{p}<0.05)$ correlations for changes in temperature $\left(\Delta^{\circ} \mathrm{C}\right)$, cross-shore wind $\left(W_{\mathrm{cs}}\right)$, north-south winds $\left(W_{\mathrm{ns}}\right)$, tidal height $(T)$, and interaction between factors on the concentration of zooplankton at the shore are shown in bold; percentage of variability (\%) explained by the model is also shown

\begin{tabular}{|c|c|c|c|c|c|}
\hline & Estimate & SE & $t$-value & $\operatorname{Pr}(>|t|)$ & $\%$ \\
\hline \multicolumn{6}{|l|}{ Gastropods } \\
\hline$\Delta^{\circ} \mathrm{C}$ & 64.93 & 119.94 & 0.54 & 0.59 & 33 \\
\hline$W_{\mathrm{ns}}$ & 140.58 & 716.59 & 0.19 & 0.84 & \\
\hline$W_{\mathrm{cs}}$ & 45.24 & 40.23 & 1.12 & 0.26 & \\
\hline$T$ & -0.01 & 0.04 & -0.35 & 0.72 & \\
\hline$\Delta^{\circ} \mathrm{C} \times W_{\mathrm{ns}}$ & -271.84 & 762.59 & -0.35 & 0.72 & \\
\hline$\Delta^{\circ} \mathrm{C} \times W_{\mathrm{cS}}$ & -169.02 & 95.75 & -1.76 & 0.08 & \\
\hline$\Delta^{\circ} \mathrm{C} \times T$ & -0.08 & 0.14 & -0.61 & 0.54 & \\
\hline$W_{\mathrm{ns}} \times W_{\mathrm{cs}}$ & 495.64 & 556.99 & 0.89 & 0.37 & \\
\hline$W_{\mathrm{ns}} \times T$ & -0.13 & 0.56 & -0.24 & 0.80 & \\
\hline$W_{\mathrm{cs}} \times T$ & -0.02 & 0.04 & -0.44 & 0.65 & \\
\hline$\Delta^{\circ} \mathbf{C} \times W_{\mathrm{ns}} \times W_{\mathrm{cs}}$ & -1909.91 & 781.43 & -2.44 & 0.01 & \\
\hline$\Delta^{\circ} \mathrm{C} \times W_{\mathrm{ns}} \times T$ & 1.02 & 0.88 & 1.15 & 0.25 & \\
\hline$\Delta^{\circ} \mathrm{C} \times W_{\mathrm{cs}} \times T$ & 0.04 & 0.12 & 0.32 & 0.74 & \\
\hline$W_{\mathrm{cs}} \times W_{\mathrm{cs}} \times T$ & -0.48 & 0.45 & -1.05 & 0.29 & \\
\hline$\Delta^{\circ} \mathbf{C} \times W_{\mathrm{ns}} \times W_{\mathrm{cs}} \times T$ & 2.35 & 0.93 & 2.52 & 0.01 & \\
\hline \multicolumn{6}{|l|}{ Foraminifera } \\
\hline$\Delta^{\circ} \mathrm{C}$ & 5.85 & 20.78 & 0.28 & 0.77 & 25 \\
\hline$W_{\mathrm{ns}}$ & 77.72 & 124.19 & 0.62 & 0.53 & \\
\hline$W_{\mathrm{cs}}$ & 11.05 & 6.97 & 1.58 & 0.11 & \\
\hline$T$ & -0.01 & 0.01 & -0.31 & 0.75 & \\
\hline$\Delta^{\circ} \mathrm{C} \times W_{\mathrm{ns}}$ & -93.36 & 132.16 & -0.70 & 0.48 & \\
\hline$\Delta^{\circ} \mathrm{C} \times W_{\mathrm{cs}}$ & -26.73 & 16.59 & -1.61 & 0.11 & \\
\hline$\Delta^{\circ} \mathrm{C} \times T$ & -0.02 & 0.02 & -0.83 & 0.40 & \\
\hline$W_{\mathrm{ns}} \times W_{\mathrm{cs}}$ & 110.04 & 96.53 & 1.14 & 0.26 & \\
\hline$W_{\mathrm{ns}} \times T$ & -0.05 & 0.09 & -0.51 & 0.60 & \\
\hline$W_{\mathrm{CS}} \times T$ & -0.01 & 0.01 & -0.53 & 0.59 & \\
\hline$\Delta^{\circ} \mathbf{C} \times W_{\mathrm{ns}} \times W_{\mathrm{cs}}$ & -322.22 & 135.43 & -2.37 & 0.02 & \\
\hline$\Delta^{\circ} \mathrm{C} \times W_{\mathrm{ns}} \times T$ & 0.17 & 0.15 & 1.15 & 0.25 & \\
\hline$\Delta^{\circ} \mathrm{C} \times W_{\mathrm{cs}} \times T$ & -0.01 & 0.02 & -0.30 & 0.75 & \\
\hline $\mathrm{WCS} \times W_{\mathrm{cs}} \times T$ & -0.08 & 0.07 & -1.09 & 0.27 & \\
\hline$\Delta^{\circ} \mathbf{C} \times W_{\mathrm{ns}} \times W_{\mathrm{cs}} \times T$ & 0.35 & 0.16 & 2.16 & 0.03 & \\
\hline \multicolumn{6}{|l|}{ Cyphonautes } \\
\hline (Intercept) & -2.59 & 1.20 & -2.07 & 0.04 & 10 \\
\hline$\Delta^{\circ} \mathrm{C}$ & 2.77 & 2.25 & 1.23 & 0.22 & \\
\hline$T$ & 0.01 & 0.01 & 2.41 & 0.01 & \\
\hline$\Delta^{\circ} \mathrm{C} \times T$ & -0.01 & 0.01 & -1.34 & 0.18 & \\
\hline \multicolumn{6}{|l|}{ Barnacle cyprids } \\
\hline$\Delta^{\circ} \mathbf{C}$ & 6.54 & 3.12 & 2.09 & 0.04 & 25 \\
\hline$W_{\mathrm{ns}}$ & 9.52 & 10.29 & 0.92 & 0.35 & \\
\hline$T$ & -0.01 & 0.01 & -0.35 & 0.72 & \\
\hline$\Delta^{\circ} \mathrm{C} \times W_{\mathrm{ns}}$ & 18.99 & 15.59 & 1.21 & 0.22 & \\
\hline$\Delta^{\circ} \mathrm{C} \times T$ & -0.01 & 0.01 & -1.00 & 0.31 & \\
\hline$W_{\mathrm{ns}} \times T$ & -0.01 & 0.01 & -1.00 & 0.31 & \\
\hline$\Delta^{\circ} \mathrm{C} \times W_{\mathrm{ns}} \times T$ & -0.01 & 0.01 & -0.37 & 0.71 & \\
\hline
\end{tabular}

role in their delivery to shore. The different results found for different sites also underscores the importance of vertical position of zooplankters in determining which transport mechanisms they are exposed to (Paris \& Cowen 2004, Hare et al. 2005, Lloyd et al. 2012a).

Larvae cross the surf zone by several means, depending on their vertical distribution. Organisms close to the bottom, such as mussels, barnacle cyprids, bivalves, foraminifera, and gastropods, sink in response to turbulence (Fuchs \& DiBacco 2011, Fuchs et al. 2013) and accumulate near the bottom at the outer edge of the surf zone. Peaks in abundance in the surf zone, for those plankters that sink in response to turbulence inside the surf zone, have been attributed to a nearbed transport mechanism driven by surface breaking waves (Navarrete et al. 2015, Pfaff et al. 2015, Shanks et al. 2015, Morgan et al. 2017, 2018). On the other hand, for organisms that remain close to the surface, such as some species of gastropods and foraminifera, the results of this study were consistent with those of previous studies showing that currents generated by onshore winds or Stokes drift might help these larvae reach the intertidal zone (Fujimura et al. 2014, Morgan et al. 2018).

Internal tidal bores, along with their interaction with onshore winds in some cases, explained the variability of barnacle cyprids, foraminifera, and late-stage gastropod larvae. Other studies have found that internal motions are capable of delivering zooplankton to reflective shores (Shanks et al. 2014, Pfaff et al. 2015). In the case of barnacle cyprids, internal tides reaching the shore explained $25 \%$ of the variability in abundance at the study site, where previous studies found that daily settlement of intertidal barnacles Chthamalus spp. has been correlated to either the internal tide (Ladah et al. 2005) or onshore winds (Valencia-Gasti \& Ladah 2016) on different occasions. However, an interaction of both mech- conditions, similar to those shown in the present study (Fig. 3d). The relationship detected between tidal height and abundance of bryozoans suggests that the incursion of water onto the shore by the tide, or some other factor related to the tide, may play a 
anisms has not been documented previously. In the present study, an interaction between onshore winds and internal waves was found for gastropods and foraminifera for the first time in this area. Previous studies collected meroplankton in the water column far from the surf zone or entailed intertidal settlement surveys at a daily frequency (Ladah et al. 2005, Liévana MacTavish et al. 2016, Valencia-Gasti \& Ladah 2016), which may be the reason the combination of mechanisms had not been detected. In the present study, we may have been able to identify both mechanisms as important due to the high frequency of sampling and the proximity to the shore, as this was the first time the abundance of zooplankton in the surf zone was determined at an hourly scale at the Bay of Todos Santos. Also, because the vertical distribution of gastropods and foraminifera species occurs throughout the whole water column when in the nearshore, exposure to both mechanisms of transport to the coast might have occurred (Kuroyanagi \& Kawahata 2004, Lloyd et al. 2012b).

The vast majority of larvae collected in the surf zone in the present study were in the later stages of development. Larval behavior, related to developmental stage, plays an important role in the horizontal and vertical distribution of these organisms. Larvae can move into different depths to take advantage of stratified currents, thus controlling their crossshore distribution (Tapia et al. 2010). Larvae may also respond to different environmental cues to change their behavior. For example, cyprids (last larval stage of barnacles) respond to downwelling in the laboratory by swimming up in the water column (DiBacco et al. 2011). This behavior can help them concentrate in internal bore warm fronts that may transport them to shore, as other authors have found, where strong thermal stratification has been related to a greater abundance of barnacle cyprids closer to shore (Hagerty et al. 2018). It has also been suggested that earlier stages of larvae located throughout most of the water column avoid the surf zone by detecting turbulence and shear from breaking waves near the coast (Fuchs \& Gerbi 2016, Morgan et al. 2017, 2018), explaining their low numbers in our samples. On the other hand, late-stage larvae of many species, including barnacles, crabs, and mussels, are more abundant in surf zones (Morgan et al. 2017, Hagerty et al. 2018), as was found herein.

Changes in abundance and vertical distribution of plankton across the shelf have been well documented (Ladah et al. 2005, Shanks 2006, Shanks et al. 2014, Liévana Mactavish et al. 2016, Valencia-Gasti \& Ladah 2016); however, there is limited information on the delivery of larvae to and in the surf zone, especially at reflective shores. In situ sampling and numerical simulations of larval transport have been performed to better understand the process (Fujimura et al. 2014, Morgan et al. 2017), yet much is still unknown. The present study represents a valuable step in comprehending how internal tidal waves and onshore winds may assist in transporting different species of larvae to shore at an hourly scale.

In the present study, delivery processes were consistent with the vertical distributions of zooplankton in the water column. These patterns may vary seasonally with wind variability and stratification of the water column, which is necessary for internal tidal motions during the year. It should be noted that the data set was only $3 \mathrm{~d}$ long; hence, the results, although statistically significant, are an early approach in understanding the delivery of larvae in the Bay of Todos Santos shores. The present study supports the hypothesis that internal tidal bores reaching the coast in summer (when the water column is strongly stratified) in concert with onshore winds can accumulate zooplankton nearshore, suggesting that in many cases and for many organisms these transport mechanisms do not act alone.

Acknowledgements. This research was funded by UCMEXUS-CONACYT CN-14-13 and SEP-CONACYT CB-201301-221662 through the Fluxes Linking the Offshore and the Onshore (FLOO) projects. The authors thank (1) the numerous volunteers from CICESE and the Autonomous University of Baja California (UABC) who enthusiastically assisted with field work and (2) the Interdisciplinary Coastal Ecology (ICE) team at CICESE and the Bodega Marine Lab for their assistance with logistics and zooplankton identification. We thank Dr. Zertuche's laboratory for assisting and providing equipment to analyze samples, Dr. Ruiz de Alegría-Arzaburu's laboratory at the UABC for providing bathymetry of Todos Santos Bay, and Alejandra Naranjo and Ignacio Romero for lab assistance.

\section{LITERATURE CITED}

Almeida M, Queiroga H (2003) Physical forcing of onshore transport of crab megalopae in the northern Portuguese upwelling system. Estuar Coast Shelf Sci 57:1091-1102

Bernstein BB, Jung N (1979) Selective pressures and coevolution in a kelp canopy community in southern California. Ecol Monogr 49:335-355

DiBacco C, Fuchs HL, Pineda J, Helfrich K (2011) Swimming behavior and velocities of barnacle cyprids in a downwelling flume. Mar Ecol Prog Ser 433:131-148

Elgar S, Herbers THC, Guza RT (1994) Reflection of ocean surface gravity waves from a natural beach. Phys Oceanogr 24:1503-1511

Fewings MS, Lentz SJ, Fredericks J (2008) Observations of cross-shelf flow driven by cross-shelf winds on the inner continental shelf. Phys Oceanogr 38:2358-2378 
Filonov A, Lavín M, Ladah L, Tereshchenko I (2014) Spatial variability of internal waves in an open bay with a narrow steep shelf in the Pacific off NW Mexico. Cont Shelf Res 78:1-15

Franks PJS (1997) Spatial patterns in dense algal blooms. Limnol Oceanogr 42:1297-1305

Fuchs HL, DiBacco C (2011) Mussel larval responses to turbulence are unaltered by larval age of light conditions. Limnol Oceanogr Fluids Environ 1:120-134

Fuchs HL, Gerbi GP (2016) Seascape-level variation in turbulence- and wave-generated hydrodynamic signals experienced by plankton. Prog Oceanogr 141:109-129

Fuchs HL, Huter EJ, Schmitt ML, Guazzo RA (2013) Active downward propulsion by oyster larvae in turbulence. J Exp Biol 216:1458-1469

Fujimura A, Reniers AJHM, Paris CB, Shanks AL, MacMahan JH, Morgan SG (2014) Numerical simulations of larval transport into a rip-channeled surf zone. Limnol Oceanogr 59:1434-1447

*Hagerty ML, Reyns N, Pineda J (2018) Constrained nearshore larval distributions and thermal stratification. Mar Ecol Prog Ser 595:105-122

* Hare JA, Thorrold S, Walsh H, Reiss C, Valle-Levinson A, Jones C (2005) Biophysical mechanisms of larval fish ingress into Chesapeake Bay. Mar Ecol Prog Ser 303:295-310

Helfrich K, Pineda J (2003) Accumulation of particles in propagating fronts. Limnol Oceanogr 48:1509-1520

Jacinto D, Cruz T (2008) Tidal settlement of the intertidal barnacles Chthamalus spp. in SW Portugal: interaction between diel and semi-lunar cycles. Mar Ecol Prog Ser 366:129-135

Kuroyanagi A, Kawahata H (2004) Vertical distribution of living planktonic foraminifera in the seas around Japan. Mar Micropaleontol 53:173-196

* Ladah LB, Tapia FJ, Pineda J, Lopez M (2005) Spatially heterogeneous, synchronous settlement of Chthamalus spp. larvae in northern Baja California. Mar Ecol Prog Ser 302:177-185

Kadah LB, Filonov A, Lavín MF, Leichter JJ, ZertucheGonzález JA, Pérez-Mayorga DM (2012) Cross-shelf transport of sub-thermocline nitrate by the internal tide and rapid (3-6 h) incorporation by an inshore macroalga. Cont Shelf Res 42:10-19

* Leichter JJ, Shellenbarger G, Genovese SJ, Wing SR (1998) Breaking internal waves on a Florida (USA) coral reef: a plankton pump at work? Mar Ecol Prog Ser 166:83-97

Leichter JJ, Deane GB, Stoked MD (2005) Spatial and temporal variability of internal wave forcing on a coral reef. J Phys Oceanogr 35:1945-1962

* Lentz SJ, Fewings M, Howd P, Fredericks J, Hathaway K (2008) Observations and a model of undertow over the inner continental shelf. J Phys Oceanogr 38:2341-2357

* Liévana MacTavish A, Ladah LB, Lavín MF, Filonov A, Tapia FJ, Leichter J (2016) High frequency (hourly) variation in vertical distribution and abundance of meroplanktonic larvae in nearshore waters during strong internal tidal forcing. Cont Shelf Res 117:92-99

Lloyd MJ, Metaxas A, deYoung B (2012a) Patterns in vertical distribution and their potential effects on transport of larval benthic invertebrates in a shallow embayment. Mar Ecol Prog Ser 469:37-52

Lloyd MJ, Metaxas A, deYoung B (2012b) Physical and biological factors affect the vertical distribution of larvae of benthic gastropods in a shallow embayment. Mar Ecol Prog Ser 464:135-151
Mateos E, Marinone SG, Parés-Sierra A (2009) Towards the numerical simulation of the summer circulation in Todos Santos Bay, Ensenada, B.C. Mexico. Ocean Model 27: $107-112$

*Morgan SG, Shanks AL, MacMahan J, Reniers AJHM, Griesemer CD, Jarvis M, Fujimura AG (2017) Surf zones regulate larval supply and zooplankton subsidies to nearshore communities. Limnol Oceanogr 62:2811-2828

* Morgan SG, Shanks AL, MacMahan JH, Reniers AJHM, Fedderson F (2018) Planktonic subsidies to surf zone and intertidal communities. Annu Rev Mar Sci 10:345-369

* Navarrete SA, Largier JL, Vera G, Tapia FJ and others (2015) Tumbling under the surf: wave-modulated settlement of intertidal mussels and the continuous settlement-relocation model. Mar Ecol Prog Ser 520:101-121

* Paris CB, Cowen RK (2004) Direct evidence of a biophysical retention mechanism for coral reef fish larvae. Limnol Oceanogr 49:1964-1979

*Pfaff MC, Branch GM, Fisher JL, Hoffmann V, Ellis AG, Largier JL (2015) Delivery of marine larvae to shore requires multiple sequential transport mechanisms. Ecology 96:1399-1410

* Pineda J (1991) Predictable upwelling and the shoreward transport of planktonic larvae by internal tidal bores. Science 253:548-551

Pineda J (1994) Internal tidal bores in the nearshore: warmwater fronts, seaward gravity currents and the onshore transport of neustonic larvae. J Mar Res 52:427-458

* Pineda J (1999) Circulation and larval distribution in internal tidal bore warm fronts. Limnol Oceanogr 44: 1400-1414

Pineda J (2000) Linking larval settlement to larval transport: assumptions, potentials, and pitfalls. Oceanogr East Pacific 1:84-105

*Pineda J, Hare J, Sponagule S (2007) Larval transport and dispersal in the coastal ocean and consequences for population connectivity. Oceanography 20:22-39

Kilov G, Dudas SE, Menge BA, Grantham BA, Lubchenco J, Schiel DR (2008) The surf zone: A semi-permeable barrier to Onshore recruitment of invertebrate larvae? J Exp Mar Biol Ecol 361:59-74

* Saunders MI, Metaxas A (2010) Physical forcing of distributions of bryozoan cyphonautes larvae in a coastal embayment. Mar Ecol Prog Ser 418:131-145

* Shanks AL (1983) Surface slicks associated with tidally forced internal waves may transport pelagic larvae of benthic invertebrates and fishes shoreward. Mar Ecol Prog Ser 13:311-315

Shanks AL (1995) Mechanisms of cross-shelf dispersal of larval invertebrates and fish. In: McEdward L (ed) Ecology of marine invertebrate larvae. CRC Press, Boca Raton, FL, p 323-368

KShanks AL (2006) Mechanisms of cross-shelf transport of crab megalopae inferred from a time series of daily abundance. Mar Biol 148:1383-1398

* Shanks AL, Largier J, Brink L, Brubaker J, Hoof R (2000) Demonstration of the onshore transport of larval invertebrates by the shoreward movement of an upwelling front. Limnol Oceanogr 45:230-236

* Shanks AL, Morgan SG, MacMahan J, Reniers AJHM and others (2014) Onshore transport of plankton by internal tides and upwelling-relaxation events. Mar Ecol Prog Ser 502:39-51

Shanks AL, MacMahan J, Morgan SG, Reniers AJHM and others (2015) Transport of larvae and detritus across the 
surf zone of a steep reflective pocket beach. Mar Ecol Prog Ser 528:71-86

Tapia FJ, Pineda J, Ocampo-Torres FJ, Fuchs HL, Parnell PE, Montero P, Ramos S (2004) High-frequency observations of wind-forced onshore transport at a coastal site in Baja California. Cont Shelf Res 24:1573-1585

Tapia FJ, DiBacco C, Jarret J, Pineda J (2010) Vertical distribution of barnacle larvae at a fixed nearshore station in southern California: Stage-specific and diel patterns. Estuar Coast Shelf Sci 86:265-270

Thornton EB, Guza TT (1983) Transformation of wave height distribution. J Geophys Res 88:5925-5938

Tilburg CE (2003) Across-shelf transport on a continental shelf: Do across-shelf winds matter? J Phys Oceanogr 33: 2675-2688

Editorial responsibility: Alejandro Gallego,

Aberdeen, UK
Valencia-Gasti JA, Ladah LB (2016) Synchronous settlement of barnacle larvae at small spatial scales correlates with both internal waves and onshore winds. Mar Ecol Prog Ser 552:195-210

*Wing SR, Largier JL, Botsford LW, Quinn JF (1995) Settlement and transport of benthic invertebrates in an intermittent upwelling region. Limnol Oceanogr 40: 316-329

*Woodson CB, Eerkes-Medrano DI, Flores-Morales A, Foley MM and others (2007) Local diurnal upwelling driven by sea breezes in northern Monterey Bay. Cont Shelf Res 27:2289-2302

Y Yoshioka PM (1982) Role of planktonic and benthic factors in the population dynamics of the bryozoan Membranipora membranacea. Ecology 63:457-468

Submitted: August 10, 2018; Accepted: June 14, 2019

Proofs received from author(s): August 26, 2019 